\title{
Publicity and Propaganda in 1930s Japan: Modernism as Method Gennifer Weisenfeld
}

Published in French as "Publicité et propagande dans le Japon des années 1930: Le modernisme comme méthode." In Jean-Jacques Tschudin and Claude Hamon, eds. La société Japonaise devant la montée du militarisme: Culture populaire et contrôle social dans les années $1930 .{ }^{1}$

Despite the apparent divide between modernism's sometimes recondite aesthetic sensibilities and the more didactic needs of corporate advertising and political propaganda, the modernist artistic movement was integral to the early development of modern Japanese promotional design, particularly in the sphere of photography. As major Japanese corporations emerged in the 1920s, it was clear that they were not just product manufacturers, but arbiters of taste who often worked in tandem with the state in directing consumer life and consumption habits through compelling visual strategies. In the 1930s, when daily life rationalization trends melded into increasingly broad-based social mobilization, these same modernist pictorial strategies began to be deployed concurrently in the dynamic realms of national publicity and propaganda (kokka senden or kokusaku senden) production, in both the graphic arts and exhibition display design. Through a close examination of the artistic production of some of the foremost commercial artists and photographers of the period, I will explore how the designers' integrative techniques exploited the affectivity of modernist manipulation of the image, effectively blurring the line between publicity and propaganda through the 1930s and beyond.

The burgeoning field of commercial design was profoundly influential in the transformation of Japanese social and cultural practices in the prewar period because the construction of recognizable brand name products helped manufacturers forge a national consumer market by the late 1930s. Print advertisements for a range of newly emerging national Japanese corporations-Morinaga Confectionary Company, Matsushita Electric, and Kaō Soap among others-reveal the extensive use of modernist imagery to promote consumer products. ${ }^{2}$ Modernist styles were popular among advertising executives and designers precisely because of their close associations with the modern, the new, the scientific, and the machine aesthetic. Not coincidentally the companies who employed modernist aesthetics were largely (although not exclusively) companies marketing new types of modern consumer products like Western- 

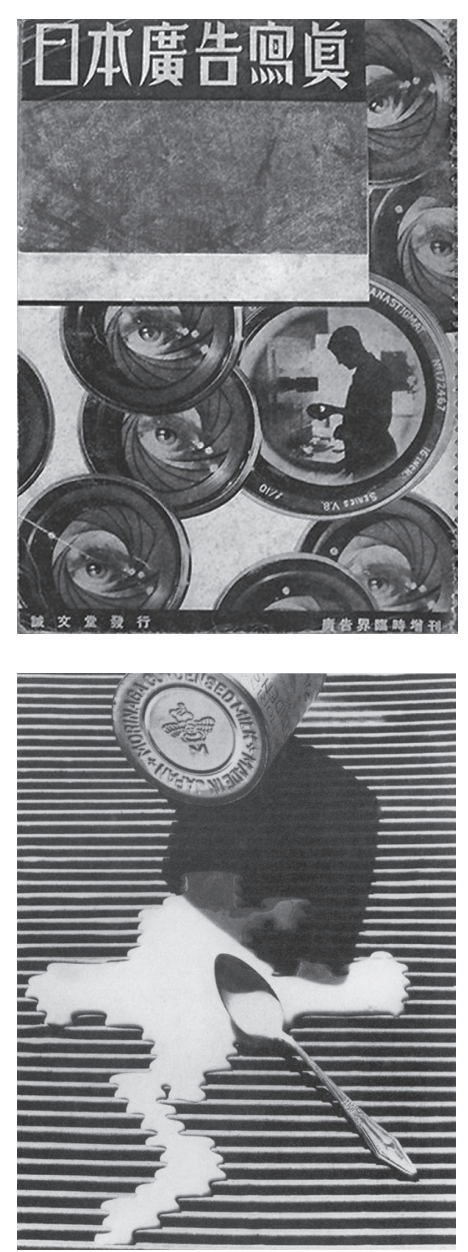

Figure 1 (top)

Cover, Nihon Kōkoku Shashin, vol. 3 (Tokyo, Seibundō, 1932).

Figure 2 (bottom)

Shimozumi Henzō, Morinaga condensed milk advertisement, Third International Advertising Photography Competition, Nihon Kōkoku Shashin, vol. 3 (Tokyo, Seibundō, 1932). style foodstuffs and new technologies—all goods that intrinsically reflected the rapidly changing nature of daily life in twentiethcentury Japan. These products straddled the line between extravagance and utility. Morinaga chocolates and caramels were marketed as delicious nutritional and healthy food for an undernourished population (particularly children); National's light bulbs not only lit up the night-time burlesques of Asakusa but also promoted healthy indoor light that enabled evening work and study, and was not detrimental to one's eyes; and Kaō high-quality cosmetic soap promoted domestic hygiene through hand and hair washing. Corporate advertising campaigns were often keyed to state policy initiatives tying private sector goals to national interests.

The utility of modernist artistic approaches in the commercial sphere was a topic widely discussed by Japanese photographers, designers, and design theorists writing in Kökokukai (Advertising World) and Photo Times. Trade journals such as these played a central role in literally and visually communicating applications of modernism to an expanding readership of professional designers, retailers, manufacturers, and interested amateurs eager for basic "how-to" information on the new fields of commercial design and photography. These trade journals, particularly Kökokukai, continued to publish well into the war years, adding various subtitles such as "industrial art and propaganda," "kokka senden" (national publicity) and "seisan bijutsu" (production art). The overlapping meanings embodied in the Japanese term senden-which was often used interchangeably with kökoku to mean advertising or publicity—reveals, however, just how fluid the boundary between advertising publicity and propaganda already was. Both entailed the art of persuasion. It bears mentioning here that advertising professionals in Euro-America during the same period similarly utilized the term propaganda as a synonym for publicity, using it to refer more neutrally to the dissemination of information by advocates of a certain cause rather than to the purveying of deliberately misleading information or the exertion of political coercion. These trade journals also continued to employ distinctly modernist aesthetics for increasingly more overtly nationalist subjects. The appeal of modernism was enduring.

From the late 1920s through the 1930s, when modernist commercial photography production was at its height, photographers advocating "shinkō shashin," or "new photography" (as modernist and avant-garde photography was commonly called in Japan) eagerly turned their skills to commercial projects, as evidenced in the hundreds of realized projects and proposals submitted to the yearly competition for International Photographic Advertising (Kokusai Shōgyō Shashin Tenrankai) sponsored by the newspaper Asahi shinbun that was launched in 1930.

Modernist photography's radical manipulation of the image in terms of viewpoint, perspective, and scale, not to mention the use of extreme close-ups, dramatic silhouettes, and shadows, provided 
Figure 3 (left)

Ueda Bizan, Kikkoman soy sauce

advertisement, Third International Advertising

Photography Competition, Nihon Kōkoku

Shashin, vol. 3 (Tokyo, Seibundō, 1932).

Figure 4 (right)

(lower right) Meiji Chocolate advertisement,

Third International Advertising Photography

Competition, Tokyo asahi shinbun, 30 March 1932,6 .
3 Asahi Shinbunsha, ed., Kokusai Kōkoku Shashinten Senshū, vol. 1 (Tokyo: Tokyo Asahi Shinbunsha, 1930).

4 Murota Kurazō, ed., Nihon Kōkoku Shashin, vol. 3 (Tokyo: Seibundō, 1932), 94.

5 Ibid., 36.

6 Ibid., 29. Appeared in the third competition announcement in Tokyo asahi shinbun, 30 (March 1932), 6.
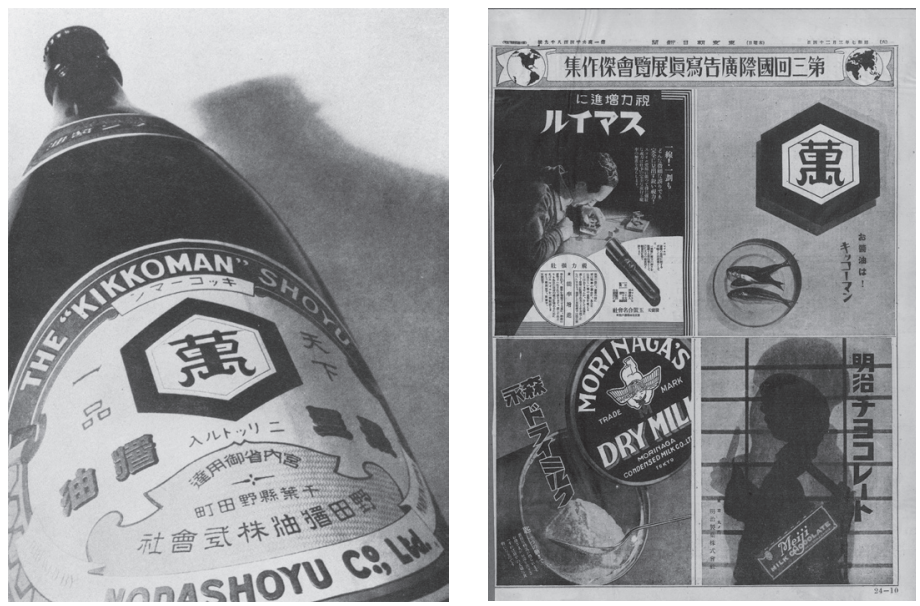

advertisers with a vocabulary of decontextualized formalism and abstraction that inherently communicated urbanity, internationalism (or at the very least cosmopolitanism), rationalism, and technological progress. And by employing integrative photographic techniques like montage and typophotos (photographs combined with innovative typographic layouts), as well as camera-less techniques like the photogram, modernism visually instantiated the technologized experience of modernity.

The winning projects were published in the Asahi Shinbun clearly emphasizing the modernist proclivity of the competition. All noteworthy submissions were collected and published in separate volumes, later issued by Seibundō under the direction of Advertising World editor Murota Kurazō. ${ }^{3}$ The cover design for the third competition volume of 1932 (Figure 1), with the multiple camera-eye images, is reminiscent of Russian director Dziga Vertov's famous film Man With a Movie Camera from 1929, in which he self-consciously fused the camera lens with the human eye (the Kino-eye) transforming man into a human camera who records the visual sensations of daily life in an expressionistic montage of unfolding images.

Inside the third volume, the stark image of Morinaga condensed milk is shown frozen dramatically as it zigzags down a corrugated surface, iridescent like a pool of liquid mercury (Figure 2). ${ }^{4}$ On another page, the exaggerated monumentalization of a Kikkoman soy sauce bottle shot dramatically from below (Figure 3) demonstrates the marketing affectivity of modernist manipulation of the image, as product photographs were refunctioned into abstract still lifes. ${ }^{5}$

A prize-winning Meiji chocolate advertisement also from the third competition (Figure 4) employs evocative silhouettes and shadows subtly suggesting consumption of the product. ${ }^{6}$ The overlapping silhouettes of two school-age figures, a boy and a girl, identifiable by their cropped hairstyles, face in opposite directions while eating chocolate bars behind the ordering grid of a shöji sliding door. In one simple visual statement, the image is simultaneously able 
Figure 5

(lower right) Morinaga chocolate advertisement, Fifth International Advertising Photography Competition, Tokyo asahi shinbun, 2 February 1934, 4-5. Morinaga \& Co., Ltd.
7 Fujimoto Michio and Shiihashi Isamu, Kōkoku Yarō Gojūnen (Tokyo: Kaosu Shokan, 1978); Morinaga Seika Kabushiki Kaisha, Morinaga Gojügonenshi (Tokyo: Morinaga Seika Kabushiki Kaisha, 1954); Morinaga Seika Kabushiki Kaisha, ed., Morinaga Seika Hyakunenshi (Tokyo: Morinaga Seika Kabushiki Kaisha, 2000).

8 Appeared in the fifth competition announcement in Tokyo asahi shinbun (February 26, 1934), 4-5.

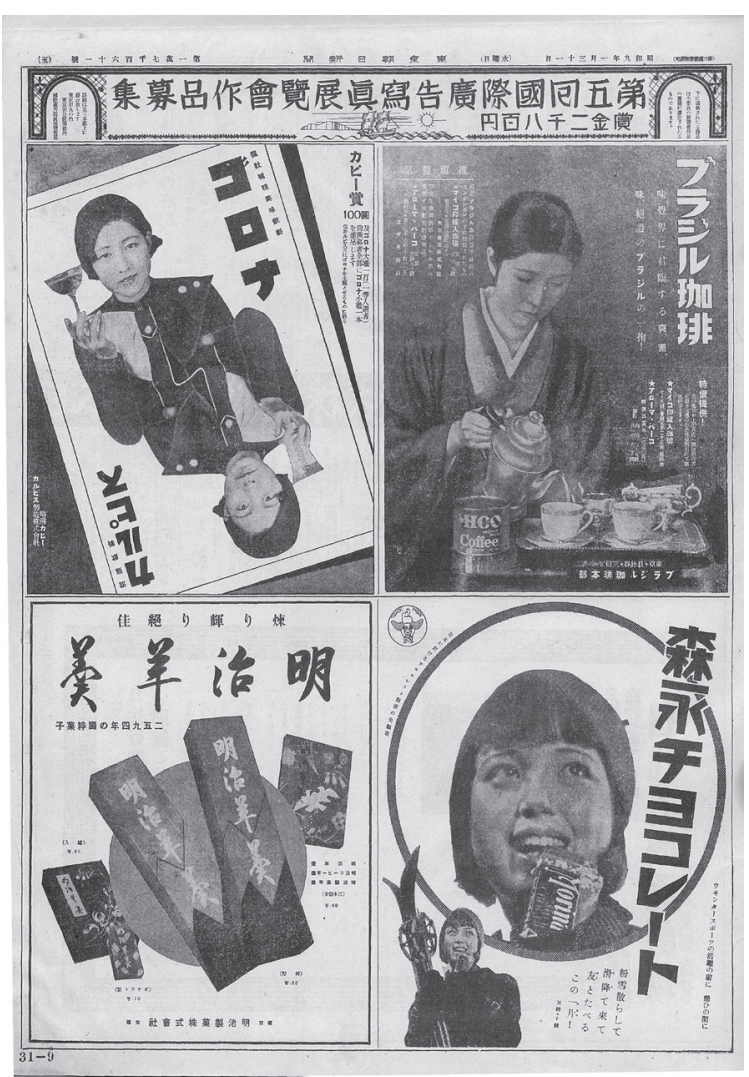

to communicate domesticity (shöi as a synecdoche of the home), childhood, and modernity (as expressed through style and the use of photography itself). The image needs no copy, it is enough to have the brand name and the floating Meiji chocolate bar at the bottom with its distinctive brand typography and wrapping to reinforce the product connection.

Morinaga was equally aggressive and innovative in its advertising design. ${ }^{7}$ The work of entrants promoting Morinaga confectionary and milk products was consistently among the noteworthy submissions selected in the Asahi photography competitions. While many of the submissions remained at the proposal stage, a number were adopted by manufacturers in their print advertisements (having already received some free publicity through the competition itself). Morinaga seems to have regularly incorporated winning submissions into its current campaigns. The paper's announcement of the fifth annual competition in February 1934 included the simple double image of a happy young woman in a smart ski outfit with her cap jauntily cocked to one side placed next to the name of the milk chocolate product rendered in its signature typography (faceted blocky katakana type) (Figure 5). ${ }^{8}$ The image reinforces the copy that proclaims Morinaga chocolate as a perfect treat to share with a friend when one hits the slopes to engage in winter sports. It was right at this time that a variety of modern western sports were being intro- 
Figure 6

Kanamaru Shigene (photographer), Meiji Shobō periodicals catalogue, 1933. Kanamaru Shigene Archive, Nihon Daigaku Collection.
9 Nihon Daigaku Geijutsu Gakubu Shashin Gakka, Kanamaru Shigene Sensei Koki Kinen (Tokyo: Kanamaru Shigene Sensei Koki Kinen Shuppan Jimukyoku Nihon Nihon Daigaku Geijutsu Gakubu Shashin Gakka, 1974).

10 Kanamaru Shigene and Suzuki Hachirō, Shögyō Shashin Jutsu (Tokyo: Ars, 1931), Kanamaru Shigene, Shinkō Shashin no Tsukurikata (Tokyo: Genkōsha, 1932). duced to Japan and they were associated with progressive modernity, leisure, and consumption. Combining disparate spheres of consumption, in this case food and sports, was an effective tactic of doubling pleasurable expectations. It is worth mentioning here again that chocolate, and Morinaga's other main product, milk caramel, were both considered in prewar Japan to be nutritional foods, offering much needed healthy calories for the still comparatively undernourished Japanese population. So for contemporary audiences, eating chocolate and skiing were both healthy activities.

The double portrait here also cinematically superimposes a framed close-up of the woman's face over her torso, tripling the leisure connotations by alluding to entertainment in moving pictures.

Perhaps one of the most prominent names in Japanese photography criticism during this time, spanning nearly fifty years from the mid 1920s until his death in 1977, was Kanamaru Shigene (19001977). ${ }^{9}$ Kanamaru was a practitioner, theorist, and educator, teaching photography at Nihon University for almost his entire professional career. Together with close friend Suzuki Hachirō, he established his own commercial photography studio, called Kinreisha, in 1926, all the while writing widely for popular photography magazines like Asahi Camera, Camera, and Photojournalism (Hödō shashin). In 1931, Kinreisha commissioned an ultra-modern photo studio building in Tokyo. Kanamaru wrote popular books on commercial photography (shōgyō shashin) as well as those on avant-garde and modernist photography (shinkō shashin), publishing Shōgyō shashin jutsu (Techniques of Commercial Photography) with Suzuki in 1931 and Shinkō shashin no tsukurikata (How to Make New Photographs) in 1932. ${ }^{10}$ He was instrumental in bringing these two spheres together for Japanese audiences. Kanamaru also continued to champion the variable applicability of these techniques for commercial and political purposes as he easily moved between the worlds of advertising and propaganda in the 1930s. His work as a photographer covered the full range of commercial services. Kanamaru closely followed developments in European and Soviet photography through a host of international design periodicals, to which he had access through

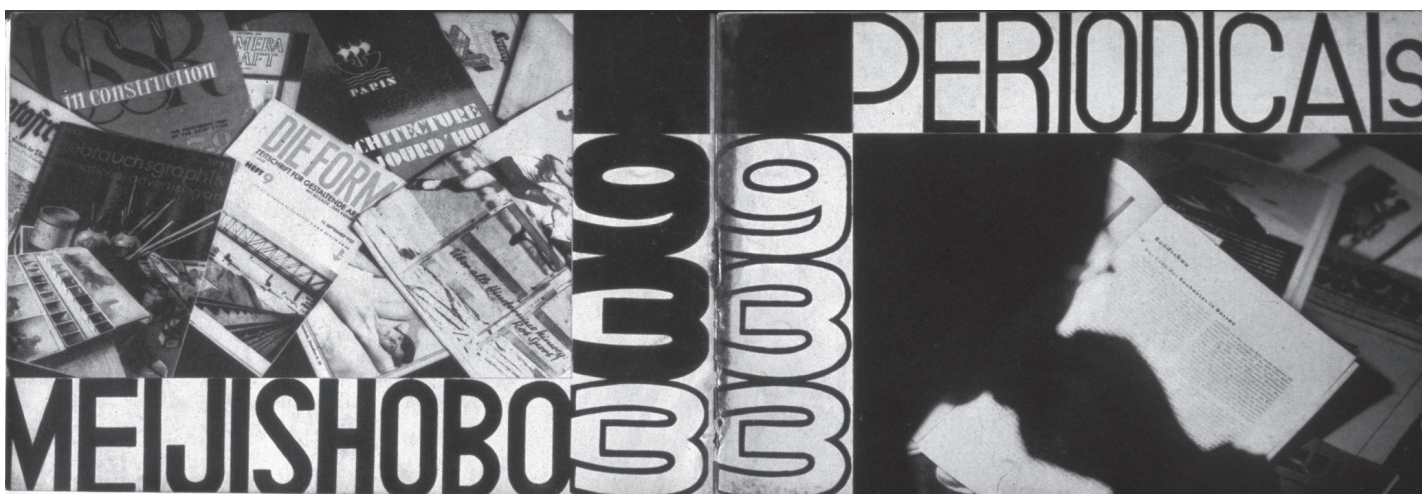


11 Both examples come from Kanamaru Shigene's personal scrapbook in the Kanamaru Shigene Archive, Nihon University. Original sources unknown.
Figure 7 (left)

Kanamaru Shigene (photographer), Maruwai applied digestive tablets advertisement, c.1931. Kanamaru Shigene Archive, Nihon Daigaku Collection.

Figure 8 (right)

Kanamaru Shigene (photographer), Daigaku Eye Medicine advertisement, c. 1931. Kanamaru Shigene Archive, Nihon Daigaku Collection.
Japanese foreign book importers like Meiji Shobō. A promotional pamphlet that Kanamaru designed for Meiji Shobō pictures an assemblage of overlapping design journals on the back cover; the titles Die Form, Architecture Aujourd'hui, and USSR in Construction are legible (Figure 6). On the cover is the silhouette of a man reading an open journal on top of the pile. Kanamaru himself had an extensive personal collection of international design publications, most notably the highly influential German design journal Gebrauchsgraphik.

The Japanese photography community had exceptionally strong ties to Germany both theoretically and in terms of actual practice, as many Japanese studied there during the prewar period. German modernist photographers who were active in commercial design were regularly featured in Japanese trade journals. Some names that repeatedly appear are: Herbert Bayer, Herbert Matter, Sasha Stone, the German-Dutch collaborative design venture Ring Neue Werbegestalter (NWG; Circle of New Advertising Designers), and Laszlo Moholy-Nagy, the well-known Hungarian-born artistphotographer who worked for many years at the Bauhaus in Germany.

As is widely known, many of these photographers championed the new multiperspectival techniques of montage and photocollage as a means of disrupting the ostensibly seamless representational mode of photography to instantiate new revolutions in visual perception, in what was often referred to at the time as factography, or what Moholy-Nagy called his "new vision." Kanamaru avidly pursued the applicability of these experimental approaches to the commercial sphere, as seen in two examples from his smallscale print advertising work. ${ }^{11}$ One is a starkly lit image of a young girl, shot from below, holding up a box of Maruwai applied digestive tablets (Figure 7). She is superimposed on a diagonal lattice of mass replicated consumers-each of these miniature figures a bathing suitclad woman raising her arms in an emancipatory gesture, presumably implying her liberation from stomach discomfort. Another of
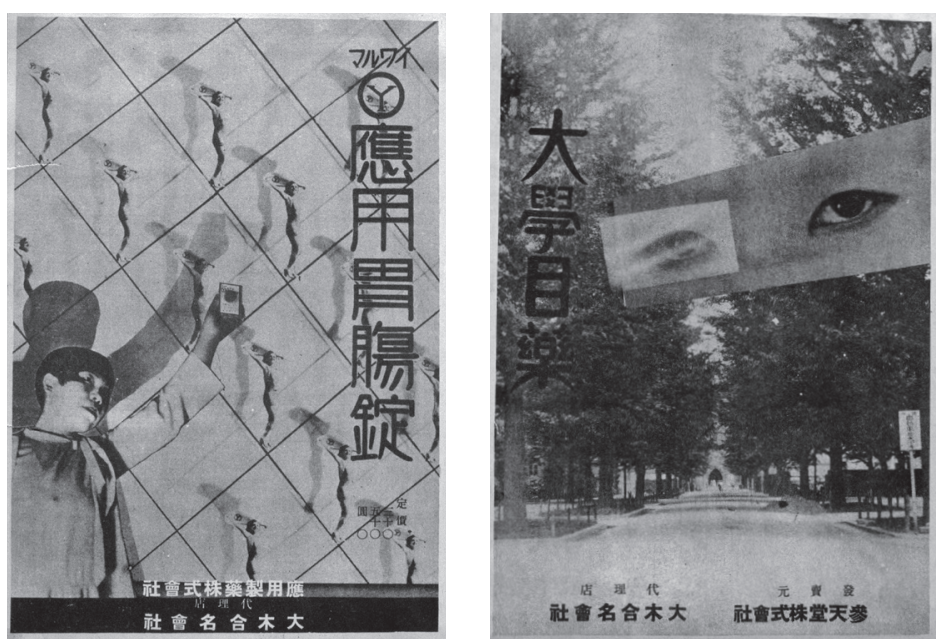

Design Issues: Volume 25, Number 4 Autumn 2009 

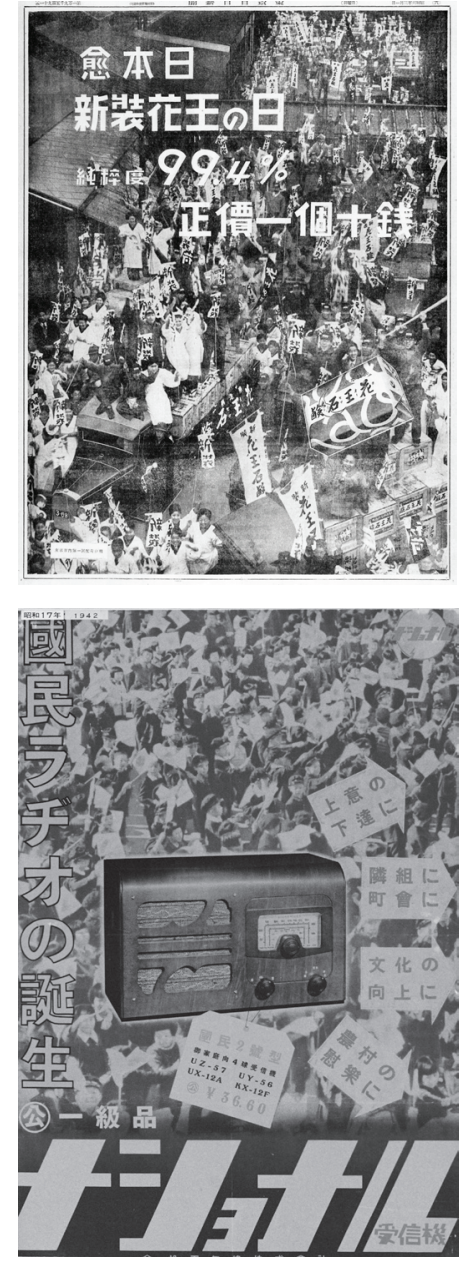

Figure 9 (top)

Ōta Hideshige (art director), Asuka Tetsuo (designer), Kanamaru Shigene (photographer), Kaō soap advertisement launching the "New and Improved Kaō" campaign (Shinsō Kaō).

Run in all major Japanese newspapers, March 1931. Kao Corporation.

Figure 10 (bottom) National Radio, poster, 1942. Office of Corporate History, Panasonic Corporation.

12 Archival records indicate that this advertisement also ran in the Osaka asahi shinbun evening edition of March 1-18, 1941. Matsushita's advertisements are illustrated in Matsushita Denki Sangyō Kabushiki Kaisha Senden Jigyōbu, Dentsū, and Dentsū Purosesu Kikaku, eds., Matsushita Denki Senden 70 Nenshi (Osaka: Matsushita Denki Sangyō, 1988).
Kanamaru's advertisement designs is a surrealistic image: a pair of disembodied eyes hovering enigmatically in the middle of a treelined road to promote Daigaku medicinal eye drops (Figure 8). In this case, Moholy-Nagy's "new vision" takes on multiple resonances, framing a new vision of commodities as well as daily life.

In the early 1930s, Kanamaru produced some distinctive work for the Kaō soap company, which in 1931 mounted a massive new advertising campaign for "New and Improved Kaō" (Shinsō Kaō) soap, overseen by the newly hired pioneering art director Ōta Hideshige (1892-1982). Kaō's “New and Improved Kaō" campaign entirely revamped the product's packaging and initiated direct marketing nationwide. The shift to direct marketing was very significant from an advertising standpoint because it meant relying even more on consumer recognition of product brand names and manufacturer identity. The full-page newspaper advertisement that kicked off the "New and Improved Kaō" campaign featured a striking photographic image shot from overhead by Kanamaru, showing all of the company employees standing outside the production factory holding up banners and energetically raising their hands in triumph (Figure 9). The copy, reminiscent of Proctor and Gamble's endorsement for Ivory soap, read "Today is the day of New and Improved Kaō, 99.4\% pure, net price 10 sen a piece." Bleeding off the edges of the image, the sea of Kaō workers seems to go on indefinitely - a flood of cheerful labor, men and women, interspersed with a convoy of Kaō soap trucks ready to charge out into the streets. The image was a response to Kaō president Nagase Tomirō II's rallying cry (printed in the new company house organ Nagaseman), in which he enjoined all employees to be soldiers in the company fight on the battlefield of the consumer market.

Curiously, Kanamaru's photograph seems to allude to triumphal images of social revolution, such as those emanating from the Soviet Union, as much as it depicts production under a capitalist system. This conflation of labor and capital in a burst of revolutionary victory presents the company as the core of an imagined community presumably surrounded by concentric rings of enthusiastic consumer-subjects who constitute the nation.

In 1942, Matsushita (under its national brand) employed a similar dramatic overhead shot of a crowd of enthusiastic young Japanese children waving national flags to promote "the birth of national radio" (kokumin rajio no tanjō)—made possible with the availability of affordable personal radios for individual household use (Figure 10)..$^{12}$ A revolutionary public communication device, the radio could be used (as the ad copy notes) for transmitting policy decisions from the authorities (jōi no katatsu ni); communicating among regional residents' associations (tonarigumi ni) and city associations (machikai), which were created in the 1940 policies of national control (kokumin tōsei); cultural improvement (bunka no kōjō); and for recreation (rest and relaxation) in rural farm villages 


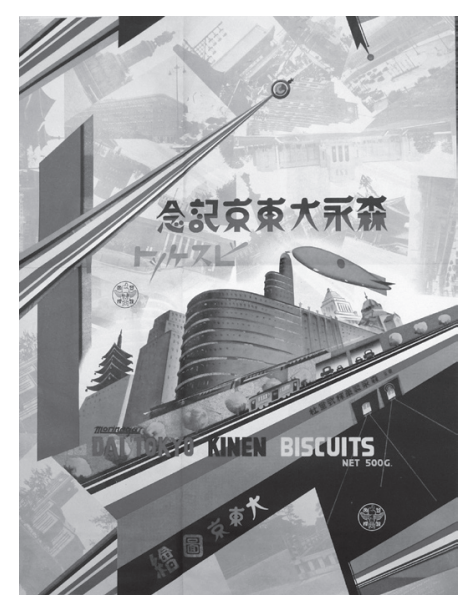

Figure 11

Morinaga Great Tokyo Commemorative Biscuits, wrapping paper, 1932. Morinaga \& Co., Ltd.
Figure 12

Morinaga Gift News, brochure, c. 1937-38.

Morinaga \& Co., Ltd.
13 In the collection of Morinaga \& Co., Ltd. (nomura no iraku). Like the montage image of the Kaō soap bar suspended over the heads of the company employees, here the radio is superimposed directly over the heads of its young listeners with dramatic arrows pointing them forward and onward. Commerce was never far from politics. Both of these dynamic spheres of visual culture production were dedicated to the act of persuasion and the glorification of iconic symbols-in one case representing political ideology, in the other, capitalist consumption.

Morinaga promotional materials also featured the montage aesthetic. In one example, it appeared in Morinaga's wrapping paper design for tins of biscuits commemorating the theme of the Great City Tokyo (Dai Tokyo Kinen Bisuketto), issued in September 1932 (Figure 11). ${ }^{13}$ This was the year that Tokyo was heralded as having finally re-emerged from the catastrophic devastation of the Great Kantō Earthquake of September 1, 1923, almost a decade earlier. The wrapping paper had a colorful graphical image of high-rise department stores, the new National Diet Building, the five-story pagoda at Sensōji temple in Asakusa, a flying Zeppelin, and a modern highspeed train, all superimposed on a faintly printed, topsy-turvy photographic montage of the city. The design echoed the cinematic kaleidoscope in German director Walther Ruttmann's landmark film, Berlin: Symphony of a Great City, released in 1927. According to archival records, the company produced 22,500 units of the commemorative biscuits.

Business historians acknowledge that Morinaga was a pioneer in marketing, especially in its development of chain store retail networks. By the late 1930s, the company had nearly 4,000 chain stores, which collectively came to be known as the Morinaga Beltline. Manufacturers found it necessary to be proactive in educating retailers in new promotional tactics, and they routinely delivered truckloads of promotional banners, leaflets, and showcases, and even sent salesmen to teach shopkeepers how to use their materials. The company published several publicity magazines for distribution at these chain stores, one was the Beltline Graph (later renamed Morinaga Beltline) and another was called simply Sweetland. That is not to

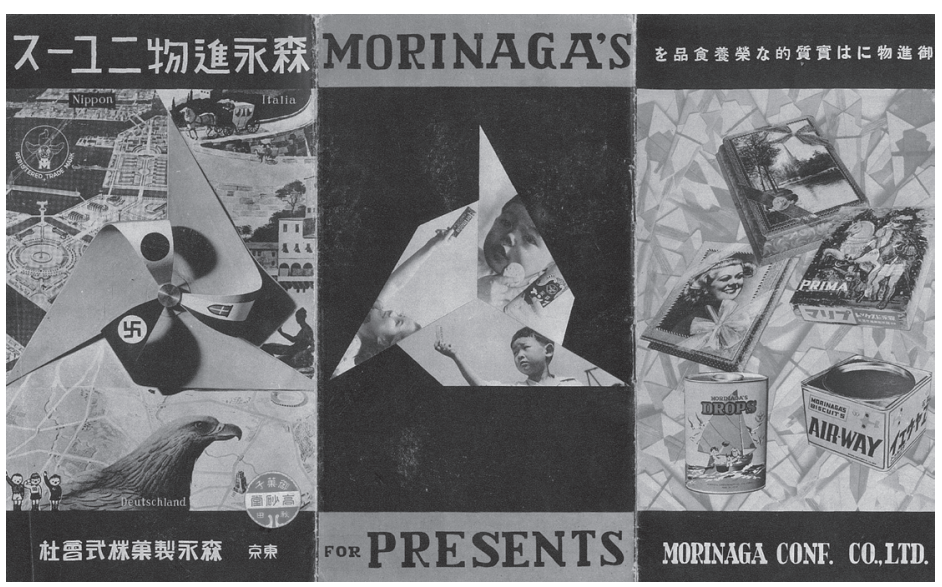

Design Issues: Volume 25, Number 4 Autumn 2009 


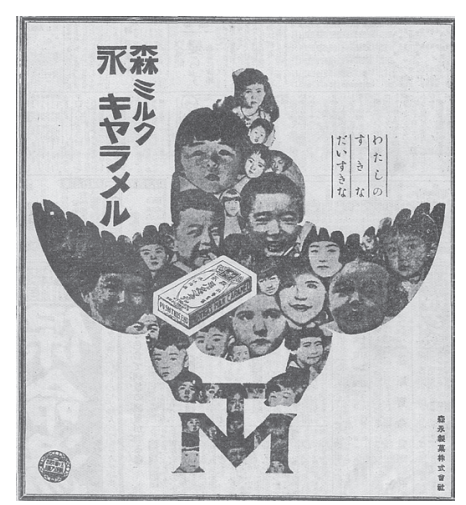

Figure 13

Morinaga milk caramels advertisement, Osaka asahi shinbun, 1 March 1929, 25. Morinaga \& Co., Ltd.
Figure 14

Tōhōsha, interior page, FRONT, special issue, Manchuokuo: An Epic, nos. 5-6, 1943.
14 In the collection of Morinaga \& Co., Ltd.

15 Osaka asahi shinbun (March 1, 1929), page unknown. mention a host of shorter pamphlets, evocatively titled Delicious, Mother's Choice, The Story of Chocolate, Candy Clan, Morinaga Gifts, and How Sweets Are Made. These magazines cleverly combined advertisements with tidbits of entertainment, cartoons, Hollywood gossip, and practical how-to information generally directed at women. They were also expertly designed in up-to-the-minute modernist graphic techniques.

Politics and current events also directly entered into the Morinaga promotional vocabulary. In a Morinaga gifts brochure marketing boxes of cookies and biscuits (probably dating from around 1937-38), montage techniques simulate images of a pinwheel featuring the national symbols of Japan, Germany, and Italy (Figure 12). ${ }^{14}$ This imagery evokes Japan's signing of the German-Japanese Agreement (the Anti-Comintern Pact) in 1936 and a protocol with Italy and Germany in Rome (on November 6, 1937) that would become the basis for the Three-Power Pact (Tripartite Alliance) creating the Axis powers (later signed in Berlin on September 27, 1940). On the front of the brochure, the pinwheel displays the national symbols over the head of a German eagle, all superimposed on a collage of urban maps and cityscapes. Three small figures of young boys with their arms raised in salute are just visible on the lower left. In the center of the brochure, the flip side of the pinwheel is rendered with three collaged images of young Japanese children holding Morinaga sweets, and the back shows floating images of Morinaga's gift products for sale.

Montage aesthetics were employed in a variety of different visual formats. In a full-page newspaper advertisement for Morinaga milk caramels (Figure 13) from the Osaka asahi shinbun (1 March 1929), a sea of smiling children's faces fills up the shape of the company logo (a registered trademark), which pictured a naked angel upside down grasping the initials "TM" for Taichirō Morinaga, the founder of the company. ${ }^{15}$

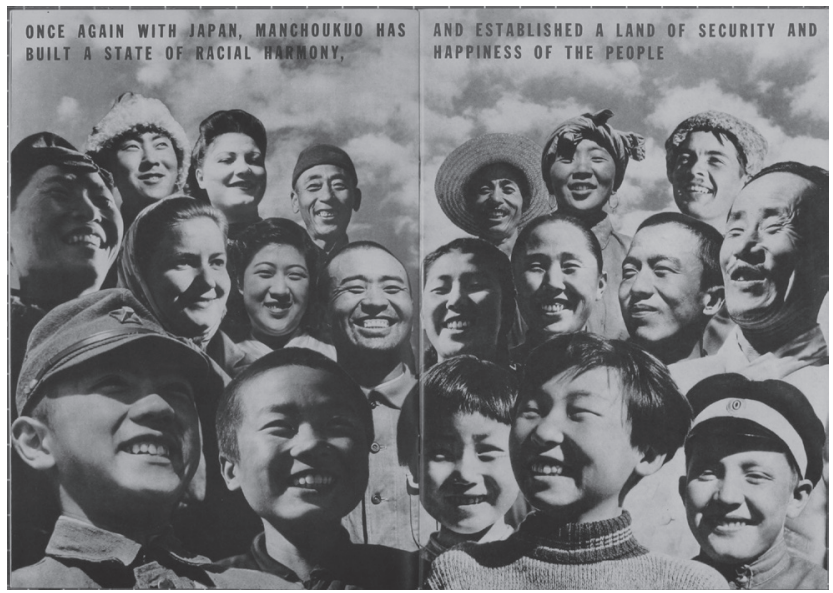

Design Issues: Volume 25, Number 4 Autumn 2009 
16 FRONT5-6 (1943). n.p.

17 Namba Kōji, Uchiteshi Yaman: Taiheiyō Sensō to Kōkoku no Gijutsushatachi, Kōdansha Sensho Mechie (Tokyo: Kōdansha, 1998), 146. For a participant's perspective see, Yamana Ayao, Imaizumi Takeji, and Arai Seiichirō, Sensō to Senden Gijutsusha: Hōdō Gijutsu Kenkyūkai no Kiroku (Tokyo: Daviddo Sha, 1978). For a recent discussion of the Hōdō Gijutsu Kenkyūkai in the larger context of Japanese wartime propaganda production, see Barak Kushner, The Thought War: Japanese Imperial Propaganda (Honolulu: University of Hawaii Press, 2006).

18 Itagaki Takaho, "Hekimen Shashin no Hattatsu to Beikoku Banpaku," Kokusai kenchiku 15:5 (1939).
The simple copy read, "Morinaga milk caramel that I like, that I love..."

Designer Hara Hiromu, who was responsible for revamping Kaō's soap packaging for the New Kaō campaign, used a similar montage of smiling figures for an interior spread in the special Manchuria issue of the wartime propaganda journal FRONT (Figure 14), published in multiple languages in the 1940s by the design company Tōhōsha. FRONT was modeled on the Soviet publication USSR in Construction, designed by El Lissitzky and Alexandr Rodchenko (the same models that Kanamaru was referring to). ${ }^{16}$ This comparison with Morinaga's light-hearted montage that constructed a community of little angels shows the malleability of this style for promoting a more overtly political message-in this case, the so-called harmonious "quinque racial state" of Manchukuo, or more generally the visionary expansionist ideology of Japan's Greater East Asia Co-Prosperity Sphere. In both images, photo collages of optimistic smiling faces create a sense of community. The arrangement in the shape of a winged angel or a bird-like figure is uplifting and exultant. Hara is subtly able to accentuate this message even further by exaggerating the perspective from below.

The dynamic advertising team at Morinaga was known throughout the larger design community in Japan, particularly because they regularly displayed their commercial work in public "art" exhibitions. They worked under prominent advertising directors Imaizumi Takeji and Arai Seiichirō) who (along with Hara and many other important advertising professionals, were later active in the wartime propaganda production group Hōdō Gijutsu Kenkyūkai (Society for the Study of Media Technology, abbreviated as Hōken) formed in 1940, which in turn worked for the Naikaku Jōhōkyoku (Cabinet Information Office). As historian Namba Kōji has argued, the standard view of the fate of commercial designers under Japan's militarist regime was that with the suspension of private corporate sponsorship their work evaporated, leaving no option but to wait until the end of the war before recommencing their careers. Focusing on the Hōken, Namba clearly demonstrates that this was not the case. Artists were able to redirect their work into state-sanctioned and state-supported areas of artistic production using their carefully honed skills in marketing and advertising to further the ideological objectives of the Japanese regime. ${ }^{17}$ I would just add that they were also able to continue their work for private corporations concurrently well into the early 1940s. In fact, as we've seen in the advertising campaigns of the 1930s, the corporate and the national were already tightly bound together, and there was no discontinuity of artistic production-from publicity to propaganda-in terms of techniques, tactics, or personnel, curiously even continuing after the war to support democratic rebuilding. In short, reactionary and progressive modernism in publicity and propaganda were cast from the same mold, and context would prove to be the deciding factor. 


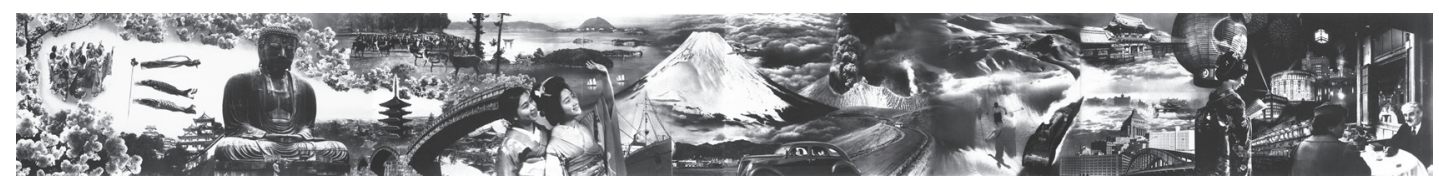

Figure 15

Hara Hiromu (designer), and Kimura Ihee, Koishi Kiyoshi, and Watanabe Yoshio (photographers), Photomural "Tourism Japan," Japanese Pavilion, Exposition Internationale de Arts et Techniques dans la Vie Moderne Paris, 1937
19 Horino's photomural was photographed by well-known photographer Kuwabara Kineo.

20 Nakai Kōichi, Komāsharu Foto=Advertising Photography (Tokyo: Shōgakukan, 1986), 22-23

21 For more on Nippon Kōbō and NIPPON, see Gennifer Weisenfeld, "Touring 'Japan as Museum': Nippon and Other Japanese Imperialist Travelogues," positions: east asia cultures critique (Winter 2000); Shirayama Mari and Hori Yoshio, eds., Natori Yōnosuke to Nippon Kōbō 1931-1945 (Tokyo: Mainichi Shinbunsha, 2006).
In the realm of the built environment, large-scale photomurals were employed by commercial and state sponsors to spatialize montage promotional aesthetics. And, according to cultural critic Itagaki Takaho writing in Kokusai kenchiku (International Architecture) in 1939, they were all over contemporary architectural journals featuring interior design schemes. ${ }^{18}$ In the fashionable Kyōbashi area of Tokyo, Morinaga's design team and freelance photographer Horino Masao created a photomural montage of a Spanish flamenco dancer for the back wall of the Morinaga Candy Store, one of the company's dessert and soda fountain parlors. ${ }^{19}$

Horino Masao, now considered one of the most well- known and respected photographers of the period, produced a number of evocative portraits and figure studies for Morinaga advertising, including a famous series of the budding actress Hara Setsuko. Hara's name is now synonymous with images of the loyal daughter and wife in classic Japanese cinema (and she will reappear later in my discussion).

Horino's modernist photography colleagues Kimura Ihee, Koishi Kiyoshi, and Watanabe Yoshio, also well-known for their work in publicity and propaganda, provided images for Hara Hiromu's composite design for the large-scale photomural promoting Japanese tourism, displayed at the 1937 World's Fair in Paris (Figure 15). ${ }^{20}$ The photomural was mounted in Japan's award-winning, modernist national pavilion, designed by architect Sakakura Junzō. Promoting the diverse leisure options of tourism in Japan, Hara's montage moves smoothly from timeless images of dancing maidens under cherry blossoms, the medieval fortress of Himeji castle, the spiritual symbol of the Great Buddha at Kamakura, and the iconic volcano of Mount Fuji, to the Japan of modernity, skiing, Tokyo's metropolis, and fine dining in the urbane capital.

The collaborative studio Nippon Kōbō, of which Hara Hiromu was initially a member, was later hired to design the interior displays of both the Japanese pavilion and the Japanese section of the Hall of Nations at the 1939-40 New York World's Fair, as well as the interior of the Japanese pavilion at the Golden Gate Exposition in San Francisco, also in 1939. These spaces were all decorated with stunning monumental photomurals. Many of the photographs used in the photomurals had already appeared in the quasi-governmental, internationally directed promotional journals produced by the same design team, Nippon Kōbō, such as the national tourism board's magazine Travel in Japan, and the multilingual journals NIPPON and COMMERCE JAPAN. 
Figure 16

Yamawaki Iwao (designer), Domon Ken (photographer), Japanese Section, Hall of Nations, New York World's Fair, 1939-40.
22 For a firsthand discussion of the project by the designer in charge see Yamawaki Iwao, "Nyu Yoku Banpaku Kokusaikan," Kokusai kenchiku 15:5 (1939); Yamawaki Iwao, "Cover[sic]d Space Japan, N.Y. World's Fair," Kokusai kenchiku 15:7 (1939); Yamawaki Iwao, "1940-Nen Nyu Yoku Banpaku Tenrankai Kokusaikan Nihonbu (Kaizō) Yamawaki Iwao Sekkei 1940," Kokusai kenchiku 16: 8 (1940); Yamawaki Iwao, "Nyu Yoku Shi Yori," Kokusai kenchiku 16:6-7 (1940).

23 Itagaki Takaho, "Hekimen Shashin no Hattatsu to Beikoku Banpaku," Kokusai kenchiku 15:5 (1939).

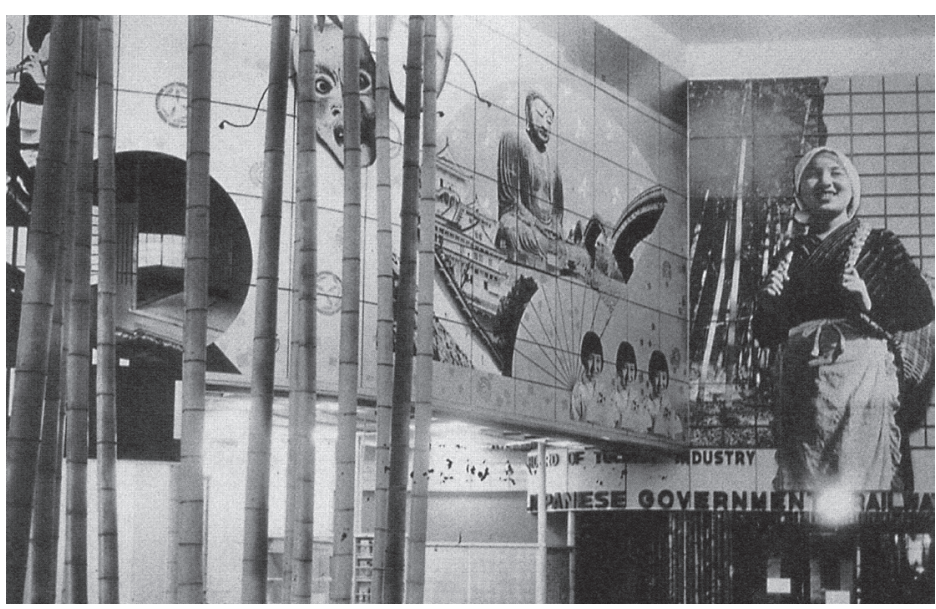

It is important to note that these journals received a combination of state and private sponsorship. NIPPON, for example, had two main sponsors. One was the Society for International Cultural Relations (known in Japanese as the Kokusai Bunka Shinkōkai), the forerunner of the Japan Foundation, a non-profit organization established under the auspices of the Ministry of Foreign Affairs in 1934..$^{21}$ The Society's self-described main objective was "the international exchange of culture and in particular the enhancement of Japanese and Oriental culture abroad, thereby to contribute toward the advancement of civilization and the promotion of human welfare." The second sponsor was the textile company Kanegafuchi Bōseki (Kanegafuchi Spinning Company), known for short as Kanebō, whose new president Tsuda Shingo provided a substantial loan to bankroll the launch of the publication. This state and private support is clearly reflected in NIPPON's integrated vision of Japanese politics, culture, and industry, which was similarly true in the exposition displays.

The dynamic use of montage in the display spaces of the expositions provided the sensation of touring, living, interactive exhibits (Figure 16). ${ }^{22}$ In the center of the room was a patch of bamboo with illuminated electric blue, yellow, and red globes at the base. The surrounding floor was covered in wisteria-purple silk carpet with circular patterns, like Japanese crests. The double-layered, illuminated ceiling rippled with cloud shapes. A large photomural (20 feet high and 58 feet wide) titled "Tourism Japan" (Kankō Nippon), sponsored by the Japanese Government Railways Tourism office, undulated across the curved space of the information desk at one end of the room near the main entrance, featuring the striking figure of a smiling female farm worker towering over the doorway, her body appearing to almost step off the wall into the viewer's space. Facing the desk on the right was a sweeping, room-size tableau of "sacred" Mount Fuji titled "Radiant Japan" (Shūrei Nippon). On the left was a series of monumental photomural panels sponsored by the International Society for Cultural Relations collectively entitled "Advancing Japan" (Yakushin Nippon). ${ }^{23}$ 
Figure 17

Yamawaki Iwao (designer), Domon Ken (photographer), "Advancing Japan," Japanese Section, Hall of Nations, New York World's Fair, 1939-40.
24 For a detailed discussion of this project, see Kawahata Naomichi, "Fusing Photography and Space: Iwao Yamawaki's Photo Murals for New York World's Fair [sic]," in Kolloquium Über Bauhausfotografie, ed. Kawasaki City Museum (Kawasaki: Kawasaki City Museum, 1997), 124-33.

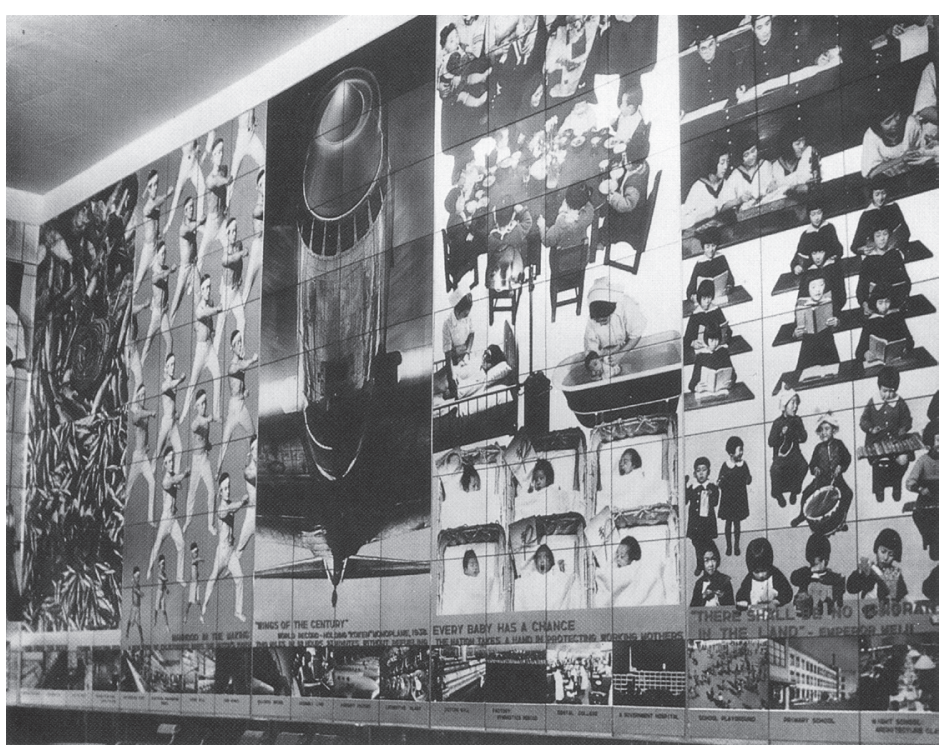

All the photomural panels were designed by Bauhaustrained architect/artist and NIPPON contributor Yamawaki Iwao (1889-1987), who used photographs in the Japanese Government Railways Board of Tourist Industry collection (many produced by Nippon Kōbō) for "Tourism Japan" and specifically commissioned works by Nippon Kōbō photographer Domon Ken for "Advancing Japan." Yamawaki declared that the photomurals were the culmination of a Bauhaus ideal of fusing photography and space..$^{24}$ Each montage panel in "Advancing Japan" was 14 feet high and nine feet wide. The panels (Figure 17) thematized aspects of Japan's social, economic, and cultural advancement such as "physical training" (taiiku), showing group exercises; "manufacturing" (kōgyō), featuring airplane production; "social health" (shakai hoken), showing a children's nursery; "science" (kagaku), featuring a cyclotron; "industry" (sangyō), spotlighting fisheries; and "education" (kyoiku), showing schoolchildren. Yamawaki's designs skillfully integrated the spatial perspective of the viewer by placing a ring of boldly captioned photographs at eye level for close inspection that were crowned by the monumental photomurals, drawing the viewer's gaze upward and across the expanse of the wall. To assure legibility and impact, he gradually increased the size of the figures as they went up the wall and punctuated the series with several panels that spotlighted a single motif such as the commanding propeller and fuselage of an airplane or a massive cyclotron. Domon's masterful modernist-inspired photographs shot from a range of dramatic angles contributed greatly to the dynamism of the compositions. The repeated, yet subtly varied figures convey a powerful impression of national unity and purpose.

When the exposition was extended for another year through 1940, it was decided to change the interior designs of the display. Yamawaki and Nippon Kōbō were again engaged to reinstall the 
Figure 18

Yamawaki Iwao (designer), "Orient Calls," Japanese Section, Hall of Nations, New York World's Fair, 1939-40.
Figure 19

Kōno Takashi (designer), Kimura Ihee, Mizoguchi Munehiro, Sugiyama Kira, and Watanabe Yoshio (photographers) "Communications," from photomural series "Transportation, Communications, Broadcasting," Japanese Pavilion, Golden Gate International Exposition San Francisco, 1939-40.

25 Suzuki Michiji, “Nyu Yoku [character illegible] Banpaku, Kokusaikan Kabādo Spēsu Nihonbu Yamawaki Iwao Sekkei," Kokusai kenchiku 15:5 (1939); Yamawaki Iwao, "1940-Nen Nyu Yoku Banpaku Tenrankai Kokusaikan Nihonbu (Kaizō) Yamawaki Iwao Sekkei 1940"; Yamawaki Iwao, "Nyu Yoku Shi Yori." The seven photographs for the "Contemporary Japanese Daily Life" photomural panels (each 12 feet by five feet) were by the following photographers respectively: farmer (Kanamaru Shigene); pilot (Okada Kōyō); mother and child (Kondō Hakuga); young woman (Kumagai Tatsuo); diver (Nakayama Iwata); business man (Watanabe Yoshio); worker (Kanamaru Shigene)

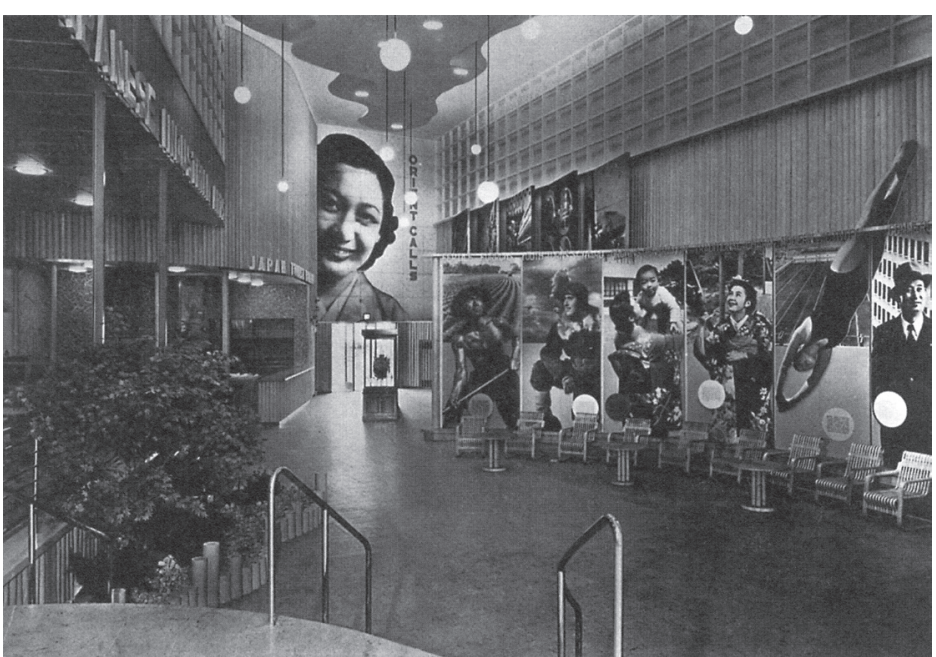

interior decoration. This time, a monumental image ( 24 feet high and 12 feet wide) of Hara Setsuko (already the face of many commercial products like Morinaga chocolate) anchored the second iteration of the display under the tourist bureau catch copy "Orient Calls" (Tōyō wa maneku) (Figure 18). The renowned gentility and amiability of the Japanese woman here beckons Western tourists to experience once again this ancient and advanced civilization of agriculture, aesthetics, industry, and sport. Looking down toward Hara Setsuko, two new sets of photomurals were installed. The first set, titled "Contemporary Japanese Daily Life" (Gendai Nippon Seikatsu), sponsored by the Asahi Shinbun, features large-scale individual figures (from left to right): a farmer under the copy "fertile furrows," (photograph by Kanamaru Shigene); a pilot with the copy "youth turns skyward"; a mother and child under "growing generation"; a woman in kimono under "traditional charms;" a female diver representing sports competition under "modern activity" (notably extending dramatically beyond the frame of the image-as if plunging into the panel); a business man under "commerce;" and a factory worker under "industry." (Incidentally, the last photograph is also by Kanamaru.) This series formed a curved backdrop to a seating area. ${ }^{25}$

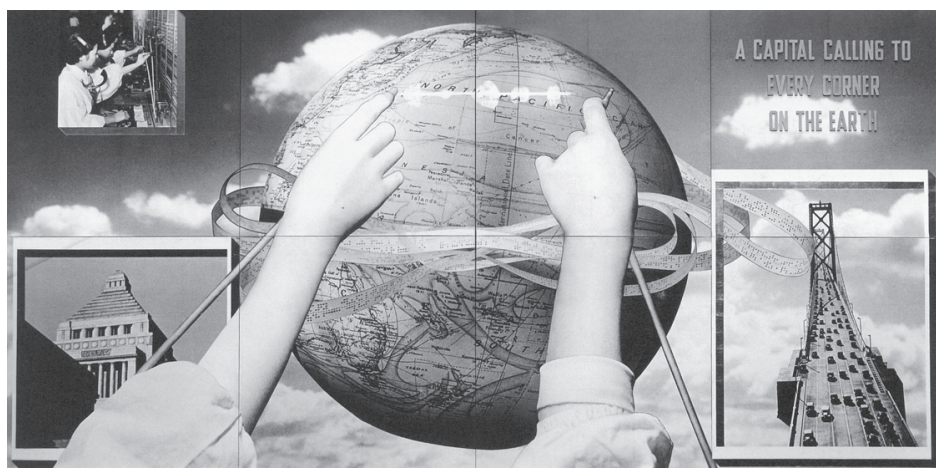

Design Issues: Volume 25, Number 4 Autumn 2009 
Figure 20

Kōno Takashi (designer), Kimura Ihee, Mizoguchi Munehiro, Sugiyama Kira, and Watanabe Yoshio (photographers), "Broadcasting," from photomural series "Transportation, Communications, Broadcasting," Japanese Pavilion, Golden Gate International Exposition San Francisco, 1939-40.
26 Reproduced in Kawahata Naomichi, Seishun zue: Kōno Takashi Shoki Sakuhinshō (Tokyo: Kōno Takashi Dezain Shiryō Shitsu, 2000), 225-32.

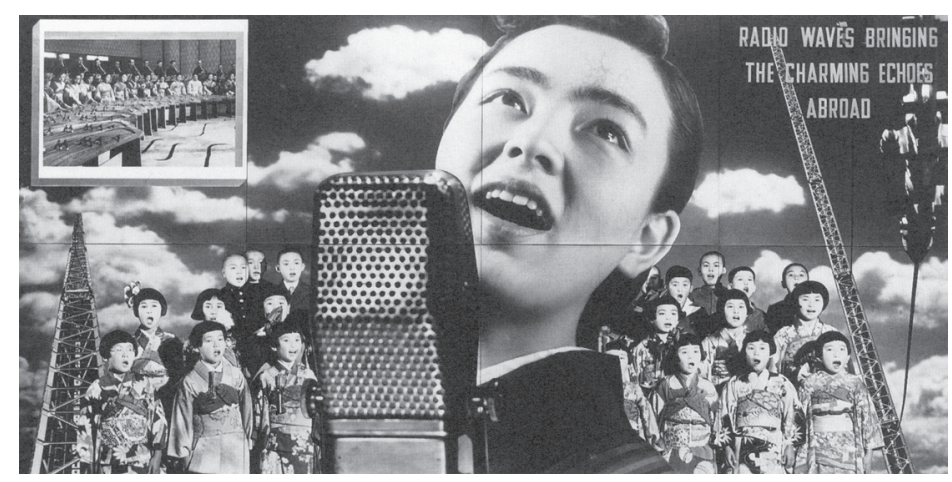

On the wall across from the information desk, above a shelf of craft displays by Kōgei Shidōsho, the Ministry of Commerce and Industry's Industrial Arts Research Division (established in 1928), was another series of dramatic montages reminiscent of the 1939 set, titled "Contemporary Industry" (Gendai no Sangyō). They were designed by Hashimoto Teruo and clearly sponsored by the Society for International Cultural Relations, Tokyo. The panels highlight Japan's "contemporary manufacturing" such as ship production ("ships for the seven seas"), its handicrafts (an "ever thriving art"), machine-made textiles ("the ... grows"), manufacturing technology (represented by "machine age men"), and aeronautics (with "airminded Japan"). The exposition envisions modern industry, daily life, and the nation-state as all intertwined. It is clear that the aestheticization of commodities through design was an integral factor in the success of many modern, consumer-oriented Japanese corporations. A new generation of professional art directors, artist-designers, and photographers, trained in professional academies and working for corporate Japan, were a major conduit for bringing a broad range of high art aesthetics into the commercial sphere, most notably, as I have discussed here, the cutting-edge modernist visual strategies of abstraction, montage, machine aesthetics, and an array of techniques for formally manipulating the photographic image.

I would like to conclude with some images, from the Japanese pavilion at the 1939 San Francisco Golden Gate World's Fair, that exemplify the use of modernism as a method for promotional publicity and propaganda. Nippon Kōbō member Kōno Takashi, who worked for the film company Shōchiku for many years, designed the photomurals, which were sponsored by the Ministry of Communications, the Ministry of Railways, and the Broadcasting Corporation of Japan. ${ }^{26}$ In one panel (Figure 19), Japan's capitalthe capital of its burgeoning empire, represented by the distinctive ziggurat-style tower of the Diet building on the lower left (completed just three years earlier in 1936) — calls to "every corner of the earth" through international telecommunications, as tickertape weaves around the globe and operators' hands extend to connect Japan and North America, framing the space of the Pacific. Just as the exposition's organizers in San Francisco were positioning the city as a criti- 

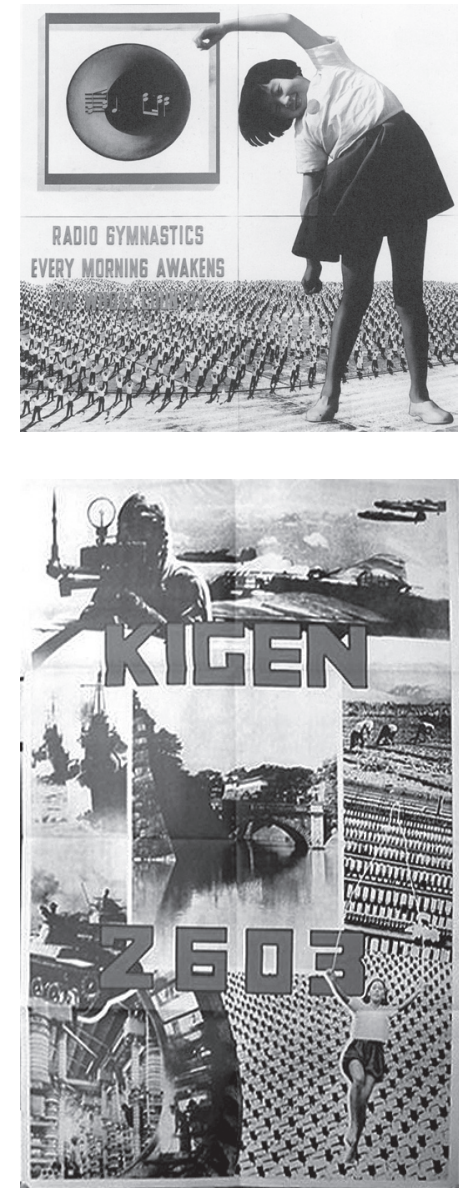

Figure 21 (top)

Kōno Takashi (designer), Kimura Ihee, Mizoguchi Munehiro, Sugiyama Kira, and Watanabe Yoshio (photographers), "Broadcasting," from photomural series "Transportation, Communications, Broadcasting," Japanese Pavilion, Golden Gate International Exposition San Francisco, 1939-40.

Figure 22 (bottom)

Hōdōbu, Kigen 2603, poster, 1943. University of Tokyo, Graduate School of Interdisciplinary Information Studies Library Collection. cal gateway to the Pacific - and America's own colonial holdings in the region-Japan counters by positioning itself on the other side of the metaphorical Pacific highway, literalized by the extending roadway of the Golden Gate Bridge on the right.

Radio, once again the unifying and information-disseminating technology highlighted earlier in Matsushita's advertisement, is featured in another panel at the fair (Figure 20), bringing "the charming echoes" of Japan abroad. Here Asia is not a recipient, but a transmitter of culture. And the radio gymnastics (rajio taisō) broadcast throughout the country train the body of the youthful and vigorous nation in another panel (Figure 21), and train it to move in unison. So just a few years later in 1943, when designers produced a montage poster to commemorate the purported 2,603rd anniversary of the legendary founding of the Japanese nation (Figure 22), the dynamic aesthetic language of modernist montage was already widely familiar to the Japanese populace, as it was one of the dominant pictorial idioms of publicity and propaganda throughout the prewar period.

\section{Acknowledgments}

I would like to express my great appreciation to Kao Corporation, Panasonic Corporation (formerly Matsushita Electric Industrial Co. Ltd.), Morinaga \& Co. Ltd., and Nihon University for their invaluable support for this project. I would specifically like to acknowledge the assistance of Professor Omuka Toshiharu, Professor Tan'o Yasunori, Professor Kashiwagi Hiroshi, Mizusawa Tsutomu, Kaneko Ryūichi, Professor Yoshimi Shunya, Ōmura Hidemasa, Ueda Kazuo, Kubota Ikuko, Tsujita Tatsuhiko, Noaki Seiji, Satō Chūkō, Ōdan Masahiro, Shirayama Mari, Professor Hara Naohisa, and Professor Takahashi Norihide. Research and writing for this essay was enabled by fellowships from the National Endowment for the Humanities, the Fulbright-Hays Program, and the Sainsbury Institute for the Study of Japanese Arts and Cultures. 